\title{
HUBUNGAN LINGKUNGAN KERJA, DISIPLIN KERJA, DAN KINERJA KARYAWAN
}

\author{
Diah Indriani Suwondo ${ }^{1^{*}}$, Eddy Madiono Sutanto ${ }^{1}$ \\ ${ }^{1}$ Program Studi Manajemen Universitas Kristen Petra \\ Jalan Siwalankerto 121-131 Surabaya 60236, Indonesia \\ *Penulis Korespondensi; Email: diah_11158@yahoo.com
}

\begin{abstract}
Abstrak
Penelitian ini bertujuan untuk menguji pengaruh lingkungan kerja dan disiplin kerja terhadap kinerja karyawan. Jenis penelitian yang digunakan adalah penelitian kuantitatif. Penelitian ini menggunakan metode sensus, yakni mengambil semua populasi menjadi responden penelitian. Jumlah responden adalah 40 orang. Teknik pengolahan dan analisis data menggunakan uji kesahihan, uji keterandalan, uji asumsi klasik, analisis deskriptif, tabulasi silang, analisis regresi linier berganda, dan analisis koefisien determinasi. Hasil penelitian menunjukkan bahwa secara individual dan secara bersama-sama lingkungan kerja dan disiplin kerja berpengaruh terhadap kinerja karyawan Bank di kota Malang. Lingkungan kerja yang nyaman dan tingkat disiplin kerja yang tinggi akan meningkatkan kinerja karyawan.
\end{abstract}

Kata kunci: Lingkungan kerja, disiplin kerja, kinerja karyawan

\begin{abstract}
This study was aimed to know the influence of work environment and work dicipline to employee performance. This type of research was quantitiative research. This study used census method, which taken all the population to survey respondents. The number of employee were 40 people. The techniques of processing and analysis data used validity test, reliability test, classic assumption test, descriptive analysis, cross tabulation, linear regression analysis, and coefficient of determination analysis. The study stated that the influence of work environment and work discipline to employee performance of bank's employees in Malang city had influence by individually and influence by simultaneously. A comfortable work environment and the high level of work discipline will to improve employee performance.
\end{abstract}

Keywords: Work environment, work discipline, employee performance

\section{Pendahuluan}

Konsep ruangan terbuka merupakan salah satu upaya yang dilakukan perusahaan untuk membangun atmosfer kerja tanpa batas. Hal ini dapat dilihat pada desain kantor Google, terutama di Indonesia. Ruangan kerja dengan pembatas yang minim dan setiap karyawan memiliki ukuran meja yang sama dapat mempermudah karyawan untuk berinteraksi dan karyawan dapat melihat atasan secara langsung. Tersedianya ruang diskusi dan ruang santai memperlihatkan bahwa Google tidak mewajibkan karyawannya untuk bekerja di meja. Hal ini bertujuan untuk mendukung terciptanya ide-ide kreatif (Erry, 2014).

Hasil penelitian yang dilakukan Cahyani dan $\mathrm{Ar}$ dana (2013) menyebutkan bahwa penataan ruang yang tepat pada tempat kerja berpengaruh terhadap kinerja karyawan. Norianggono, Hamid, dan Ruhana (2014) menyebutkan bahwa distribusi cahaya yang cukup, pemilihan warna dinding yang tepat, sirkulasi udara, dan suhu udara yang sesuai dengan ruangan juga memberikan pengaruh terhadap kinerja karyawan. Kurangnya distribusi cahaya dalam ruangan kerja akan mengakibatkan karyawan tidak dapat bekerja dengan cepat dan tepat. Hasil penelitian yang dilakukan oleh Agastia (2014) menyebutkan bahwa ketenangan bekerja juga diperlukan oleh setiap karyawan untuk melakukan pekerjaannya.

Febriani dan Indrawati (2013) dan Situngkir (2013) menyebutkan bahwa penjagaan kenyamanan dan kebersihan lingkungan kerja merupakan faktor yang mempengaruhi karyawan dalam menyelesaikan pekerjaannya. Hasil penelitian yang dilakukan Sanjaya dan Indrawati (2014) menyebutkan bahwa pembinaan hubungan antar karyawan dengan karyawan lain dan atasan dapat menciptakan lingkungan kerja yang baik, yang nantinya akan dapat berpengaruh terhadap kinerja karyawan di perusahaan. Hasil yang diperoleh dari penelitian Setiawan dan Dewi (2014) adalah kerja sama antar karyawan juga perlu ditingkatkan agar pekerjaan dapat diselesaikan dengan tepat dan sesuai target. 
Pramana dan Sudharma (2013) menyebutkan bahwa disiplin kerja juga akan mempengaruhi kinerja karyawan. Hasil penelitian yang diperoleh Rofi (2012) menyebutkan bahwa disiplin kerja karyawan merupakan faktor yang paling dominan. Hal ini perlu ditingkatkan agar harapan karyawan dapat tercapai dan mendapatkan kepuasan dalam bekerja. Dwipayana (2014) juga menyebutkan perusahaan harus memberikan sanksi bagi karyawan yang melanggar aturan dan melakukan pengawasan yang lebih ketat untuk meningkatkan kinerja karyawan. Krisnanda dan Sudibya (2014) dan Kepakisan (2014) menyebutkan bahwa perusahaan harus tegas dan tepat dalam memutuskan sanksi apa yang akan diberikan kepada karyawan agar karyawan yang melanggar aturan maupun tata tertib perusahaan tidak akan melakukan kesalahan yang sama.

Hasil penelitian yang dilakukan oleh Parhusip, Musadieq, dan Nurtjahjono (2014) dan Ariana dan Riana (2013) menyebutkan bahwa sanksi yang diberikan tidak hanya bagi karyawan yang datang terlambat atau pulang sebelum jam kerja berakhir, tetapi juga berlaku bagi karyawan yang tidak dapat menyelesaikan pekerjaannya dengan tepat waktu. Menurut Branham (2010), para atasan yang telah melakukan pengawasan lebih ketat tanpa didukung dengan kesadaran karyawan mengenai disiplin kerja, maka akan terus terjadi pelanggaran yang nantinya akan berdampak terhadap kinerja karyawan (dalam Prabasari \& Netra, 2013).

Setiap perusahaan memiliki lingkungan kerja dan disiplin kerja yang berbeda-beda sehingga dapat mempengaruhi kinerja karyawan. Suasana di tempat kerja pada Bank di kota Malang tergolong nyaman. Hal ini dikarenakan tersedianya AC (air condition) sebagai penunjang terciptanya suasana nyaman dan tingkat pencahayaan yang terang. Hanya saja, di tempat kerja tersebut tidak terlihat adanya jendela yang berfungsi sebagai perputaran udara. Di Bank tersebut terdapat beberapa ruang kerja yang tertata rapi, teratur dan sesuai dengan kebutuhan. Saat peneliti melakukan kunjungan jarang terlihat adanya komunikasi antara karyawan dengan pemimpin perusahaan dan terlihat beberapa karyawan keluar bersama saat jam istirahat. Disiplin kerja karyawan dapat dilihat dari kepatuhan karyawan pada peraturan perusahaan, cara berpakaian dan kesiapan karyawan dalam memperbaiki kesalahan. Berdasarkan fenomena tersebut, penelitian ini ingin mengetahui pengaruh lingkungan kerja dan disiplin kerja pada kinerja karyawan.

Berdasarkan latar belakang di atas, maka terdapat tiga rumusan masalah dalam penelitian ini, yaitu ingin mengetahui apakah lingkungan kerja berpengaruh terhadap kinerja karyawan, apakah disiplin kerja berpengaruh terhadap kinerja karyawan, dan mengetahui apakah lingkungan kerja dan disiplin kerja berpengaruh terhadap kinerja karyawan. Tujuan penelitian ini adalah untuk mengetahui apakah lingkungan kerja berpengaruh terhadap kinerja karyawan, apakah disiplin kerja berpengaruh terhadap kinerja karyawan, dan mengetahui apakah lingkungan kerja dan disiplin kerja berpengaruh terhadap kinerja karyawan.

\section{Lingkungan Kerja}

Menurut Sutrisno (2009) lingkungan kerja adalah keseluruhan sarana dan prasarana kerja yang ada di sekitar karyawan yang sedang melakukan pekerjaan yang dapat mempengaruhi pelaksanaan pekerjaan (p.118). Nitisemito (2006) menyatakan bahwa lingkungan kerja merupakan kondisi dari segala sesuatu yang terdapat di sekitar tempat bekerja karyawan yang mampu memberikan pengaruh bagi dirinya dalam melaksanakan pekerjaannya (dalam Yasa \& Utama, 2014).

Menurut Wursanto (2009), lingkungan kerja terdiri atas dua jenis. Pertama, lingkungan kerja yang menyangkut segi fisik adalah segala sesuatu yang menyangkut segi fisik dalam lingkungan kerja. Kedua, lingkungan kerja yang menyangkut segi psikis adalah lingkungan kerja yang tidak dapat ditangkap dengan panca indera (dalam Dharmawan, 2011).

Sedarmayanti (2007) membagi lingkungan kerja menjadi dua jenis, yaitu lingkungan kerja fisik dan non fisik. Lingkungan kerja fisik adalah semua keadaan berbentuk fisik yang terdapat di sekitar tempat kerja yang dapat mempengaruhi karyawan baik secara langsung maupun tidak langsung. Lingkungan kerja fisik dibagi menjadi dua kategori, yaitu lingkungan yang berhubungan langsung dan berada di dekat karyawan (kursi, meja dan sebagainya) dan lingkungan perantara (temperatur, kelembaban, sirkulasi udara, pencahayaan, getaran mekanis, bau tidak sedap, warna dan sebagainya). Lingkungan kerja non fisik adalah semua keadaan yang terjadi berkaitan dengan hubungan kerja, baik hubungan dengan atasan maupun hubungan dengan sesama rekan kerja maupun hubungan dengan bawahan (dalam Norianggono, Hamid, \& Ruhana, 2014).

\section{Disiplin Kerja}

Siagan (2014) menyatakan bahwa disiplin kerja merupakan tindakan manajemen untuk mendorong para anggota organisasi memenuhi tuntutan berbagai ketentuan. Disiplin kerja adalah sikap, tingkah laku dan perbuatan yang sesuai dengan peraturan organi- 
sasi baik tertulis maupun tidak tertulis (Sutrisno, 2009). Disiplin kerja merupakan bagian atau variabel yang sangat penting dalam pengembangan sumber daya manusia. Oleh karena itu, disiplin kerja diperlukan dalam suatu organisasi agar tidak terjadi keteledoran, penyimpangan atau kelalaian yang menyebabkan terjadinya pemborosan dalam melakukan pekerjaan (Nurcahyo, 2011). Disiplin kerja adalah suatu alat yang digunakan para manajer untuk berkomunikasi dengan karyawan agar bersedia mengubah perilaku serta sebagai upaya untuk meningkatkan kesadaran dan kesediaan seseorang mentaati semua peraturan perusahaan dan norma-norma sosial yang berlaku (Rivai \& Sagala, 2009, p. 825).

Disiplin kerja memberikan manfaat yang besar bagi perusahaan maupun bagi para karyawan. Bagi perusahaan, adanya disiplin kerja akan menjamin terpeliharanya tata tertib dan kelancaran pelaksanaan tugas sehingga diperoleh hasil yang optimal. Bagi karyawan, disiplin kerja akan menciptakan suasana kerja yang menyenangkan dan semangat kerja karyawan juga bertambah. Hal ini membuat karyawan dapat melaksanakan pekerjaannya dengan penuh kesadaran (Sutrisno, 2009).

Perusahaan harus menciptakan peraturan atau tata tertib dalam pelaksanaan disiplin kerja. Peraturan atau tata tertib yang diciptakan harus dipatuhi oleh seluruh karyawan dalam perusahaan. Menurut Singodimedjo (2002), peraturan-peraturan yang berkaitan dengan disiplin kerja, antara lain 1) Peraturan jam masuk, pulang, dan jam istirahat 2) Peraturan dasar tentang berpakaian dan bertingkah laku dalam pekerjaan 3) Peraturan cara-cara melakukan pekerjaan dan berhubungan dengan unit kerja lain 4) Peraturan tentang apa yang boleh dan apa yang tidak boleh dilakukan oleh karyawan selama dalam perusahaan (dalam Sutrisno, 2009).

Hasibuan (2003) menyatakan bahwa disiplin kerja yang baik adalah apabila karyawan mematuhi peraturan, yakni karyawan datang tepat waktu, tertib dan teratur. Tepat waktu, tertib dan teratur yang dimiliki oleh karyawan menandakan bahwa karyawan tersebut memiliki disiplin kerja yang tinggi, sehingga memberi pengaruh terhadap kinerja karyawan tersebut. Kedua, berpakaian rapi. Berpakaian rapi juga didukung dengan seragam yang sesuai dengan atribut yang telah ditentukan. Karyawan yang menggunakan seragam dan atribut yang sesuai dengan ketentuan menandakan bahwa karyawan tersebut mematuhi peraturan perusahaan. Hal ini juga dapat memberikan kepercayaan diri kepada karyawan sehingga kinerja karyawan tersebut meningkat. Ketiga, mampu menggunakan perlengkapan kerja dengan hati-hati. Sikap hati-hati yang ditunjukkan karyawan dapat di- artikan bahwa karyawan tersebut tidak menghindar dari kewajibannya. Hal ini menandakan bahwa disiplin kerja telah dimiliki oleh karyawan tersebut. Keempat, mengikuti cara kerja yang ditentukan oleh perusahaan. Karyawan yang mengikuti cara kerja dan peraturan yang telah ditentukan oleh perusahaan, maka disiplin kerja karyawan memberikan pengaruh terhadap kinerjanya. Kelima, memiliki tanggung jawab yang tinggi. Tanggung jawab yang tinggi mempengaruhi disiplin kerja. Karyawan yang memiliki tanggung jawab terhadap segala sesuatu menandakan bahwa karyawan tersebut memiliki tingkat disiplin kerja yang tinggi (Ardiansyah \& Wasilawati, 2014).

\section{Kinerja Karyawan}

Colquitt, LePine, dan Wesson (2011) menyatakan bahwa kinerja karyawan adalah serangkaian perilaku karyawan yang memberi kontribusi, baik secara positif maupun negatif terhadap penyelesaian tujuan organisasi (dalam Wibowo, 2007, p.2). Kinerja karyawan merupakan hasil kerja karyawan yakni sebuah proses manajemen atau suatu organisasi secara keseluruhan yang hasil kerjanya tersebut harus dapat ditunjukkan buktinya secara konkrit dan dapat diukur (Sedarmayanti, 2007,). Pendapat lain menyatakan bahwa kinerja karyawan adalah hasil pekerjaan yang dicapai oleh seseorang berdasarkan persyaratan-persyaratan pekerjaan (Bangun, 2012). Menurut Mangkunegara (2009), kinerja karyawan adalah hasil kerja secara kualitatif dan kuantitatif yang dicapai oleh seorang karyawan dalam melaksanakan tugasnya sesuai dengan tanggung jawab yang diberikan (dalam Norianggono, Hamid, \& Ruhana, 2014). Menurut Tohardi (2002), faktor-faktor yang mempengaruhi kinerja karyawan adalah pendidikan, keterampilan, disiplin kerja, budaya, dan etika kerja, manajemen, tingkat penghasilan, kesempatan berprestasi, beban pekerjaan, lingkungan kerja dan teknologi (dalam Indrajaya \& Adnyani, 2013).

Pengukuran kinerja karyawan penting dilakukan. Tujuan pengukuran kinerja adalah untuk mengetahui apakah karyawan mampu menyelesaikan kewajibannya sesuai dengan waktu yang telah ditentukan atau apakah karyawan menyimpang dari rencana yang telah ditetapkan atau apakah hasil kinerja yang telah dircapai karyawan sesuai dengan yang diharapkan. Pengukuran kinerja karyawan dapat dilakukan terhadap kinerja yang nyata dan terukur. Oleh karena itu, dibutuhkan ukuran kinerja yang bersifat kuantitatif atau dapat dihitung. Suatu pekerjaan dapat diukur melalui kuantitas dan kualitas pekerjaan, ketepatan waktu, kehadiran dan kemampuan kerja sama (Wibowo, 2007, p.155; Abdullah, 2014, p.146). 
Pengukuran kinerja diarahkan pada enam aspek, yaitu hasil kerja, pengetahuan pekerjaan, inisiatif, kecekatan mental, sikap, disiplin waktu dan absensi (Sutrisno, 2009).

\section{Kerangka Berpikir}

Kerangka berpikir yang pertama dalam penelitian ini adalah ingin melihat pengaruh lingkungan kerja terhadap kinerja karyawan. Kerangka berpikir selanjutnya ingin melihat pengaruh disiplin kerja terhadap kinerja karyawan. Kerangka berpikir yang terakhir ingin melihat pengaruh lingkungan kerja dan disiplin kerja terhadap kinerja karyawan. Lingkungan kerja dan disiplin kerja merupakan variabel bebas yang masing-masing memiliki indikator. Indikator lingkungan kerja terdiri atas suhu udara di tempat kerja, tata ruang di tempat kerja, sirkulasi udara di tempat kerja, tingkat pencahayaan di tempat kerja, hubungan antar karyawan di tempat kerja, dan hubungan karyawan dengan pemimpin perusahaan di tempat kerja (Sedarmayanti, 2007). Indikator disiplin kerja adalah ketepatan waktu bekerja, kerapian berpakaian, kepatuhan pada peraturan perusahaan dan tanggung jawab (Singodimedjo, 2002; Hasibuan, 2003). Variabel terikat dalam penelitian ini adalah kinerja karyawan yang indikatornya ketepatan waktu dalam menyelesaikan pekerjaan, tingkat inisiatif karyawan, dan kemampuan dalam bekerja sama (Bangun, 2012; Sutrisno, 2009).

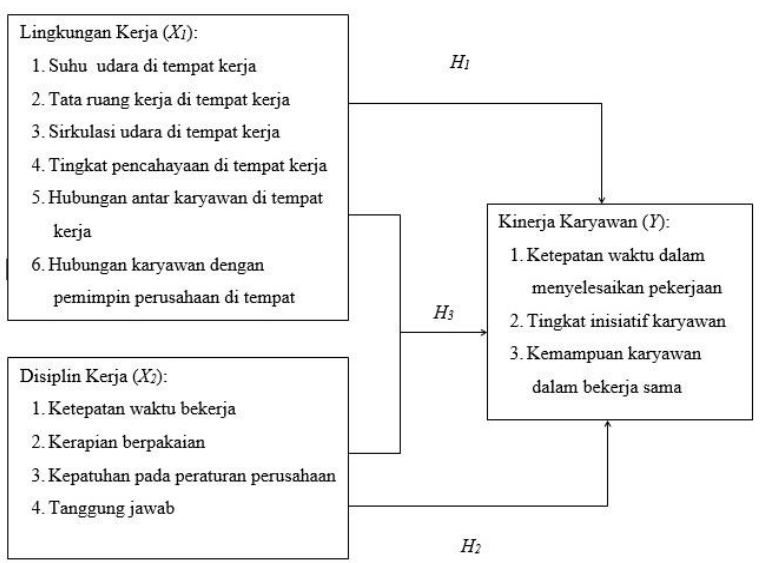

Gambar 1. Kerangka Berpikir

Sumber: Sedarmayanti (2009); Sutrino (2009); Ardiansyah dan Wasilawati (2014); bangun (2012); Sutrisno (2009)

\section{Hipotesis Penelitian}

Hasil penelitian sebelumnya menunjukkan bahwa lingkungan kerja (fisik dan non fisik) berpengaruh terhadap kinerja karyawan. Penelitian yang dilakukan Cahyani dan Ardana (2013) menunjukkan bahwa penataan ruang yang tepat pada tempat kerja akan berpengaruh terhadap kinerja karyawan. Penataan ruang ini harus didukung dengan distribusi cahaya yang cukup, pemilihan warna dinding yang tepat, sirkulasi udara dan suhu udara sesuai dengan ruangan (Norianggono, Hamid, \& Ruhana, 2014). Kurangnya distribusi cahaya dalam setiap ruangan karyawan akan mengakibatkan karyawan tidak dapat bekerja dengan cepat dan tepat. Ketenangan bekerja juga diperlukan oleh setiap karyawan untuk melakukan pekerjaannya (Agastia, 2014). Berdasarkan hasil penelitian sebelumnya, dapat dirumuskan hipotesis sebagai berikut:

$H_{l}$ : Lingkungan kerja berpengaruh terhadap kinerja karyawan.

Menurut Rofi (2012), disiplin kerja karyawan merupakan faktor yang paling dominan sehingga disiplin kerja perlu ditingkatkan agar harapan karyawan dapat tercapai dan mendapatkan kepuasan dalam bekerja. Hal ini dapat meningkatkan kinerja karyawan tersebut. Perusahaan harus memberikan sanksi bagi karyawan yang melanggar aturan dan melakukan pengawasan yang lebih ketat untuk meningkatkan kinerja karyawan (Dwipayana, 2014). Sanksi yang diberikan harus tepat sehingga karyawan yang melanggar aturan maupun tata tertib perusahaan tidak melakukan kesalahan yang sama (Krisnanda \& Sudibya, 2014). Berdasarkan penelitian sebelumnya mengenai disiplin kerja dan kinerja karyawan, dapat dirumuskan hipotesis sebagai berikut:

$\mathrm{H}_{2}$ : Disiplin kerja berpengaruh terhadap kinerja karyawan.

Lingkungan kerja yang nyaman dapat menjamin karyawan bersemangat dalam bekerja (Pramana \& Sudharman, 2013). Hal ini menunjukkan bahwa karyawan tersebut memiliki tanggung jawab yang besar sehingga dapat meningkatkan kinerjanya. Perasaan senang yang ditunjukkan oleh karyawan dan kecocokan karyawan dengan peraturan perusahaan mencerminkan lingkungan kerja yang nyaman. Hal tersebut dapat meningkatkan kinerja karyawan tersebut (Suryadi \& Rosyidi, 2013). Berdasarkan penelitian terdahulu, dapat dirumuskan hipotesis sebagai berikut:

$H_{3}$ : Lingkungan kerja dan disiplin kerja berpengaruh terhadap kinerja karyawan.

\section{Metode Penelitian}

Jenis penelitian ini adalah penelitian kuantitatif. Penelitian ini bertujuan untuk menguji hipotesis yang telah ditetapkan dan untuk mengetahui pengaruh variabel bebas (independent) terhadap variabel terikat (dependent). Penelitian ini memiliki objek penelitian, 
yaitu lingkungan kerja, disiplin kerja dan kinerja karyawan, serta karyawan suatu bank cabang kota Malang menjadi subjek penelitian. Populasi dalam penelitian ini adalah karyawan tetap sebanyak 40 orang dan sampel dalam penelitian adalah seluruh anggota populasi. Teknik pengambilan sampel dalam penelitian ini menggunakan metode sensus.

Dalam penelitian ini terdapat tiga variabel, yaitu lingkungan kerja, disiplin kerja dan kinerja karyawan. Pertama, lingkungan kerja adalah kondisi tempat kerja (sarana dan prasarana) yang memberikan pengaruh bagi diri sendiri dalam melaksanakan pekerjaannya. Indikator lingkungan kerja adalah suhu udara di tempat kerja, tata ruang di tempat kerja, sirkulasi udara di tempat kerja, tingkat pencahayaan di tempat kerja, hubungan antar karyawan di tempat kerja dan hubungan karyawan dengan pemimpin perusahaan di tempat kerja (Sedarmayanti, 2007).

Kedua, disiplin kerja adalah sikap, tingkah laku dan perbuatan seseorang yang sesuai dengan peraturan organisasi sebagai upaya meningkatkan kesadaran dan kesediaan seseorang agar tidak melakukan keteledoran, penyimpangan atau kelalaian dalam melakukan pekerjaan. Indikator disiplin kerja adalah ketepatan waktu bekerja, kerapian berpakaian, kepatuhan pada aturan perusahaan dan tanggung jawab (Singodimedjo, 2002; Hasibuan, 2003).

Ketiga, kinerja karyawan merupakan hasil pekerjaan karyawan yang diukur secara kualitatif dan kuantitatif yang dicapai dengan cara memberikan kontribusi baik positif maupun negatif dalam melaksanakan pekerjaan sesuai dengan tanggung jawabnya. Indikator kinerja karyawan adalah ketepatan dalam menyelesaikan pekerjaan, tingkat inisiatif karyawan dan kemampuan karyawan dalam bekerja sama (Bangun, 2012; Sutrisno, 2009).

Teknik pengumpulan data yang digunakan dalam penelitian ini adalah angket. Angket tersebut terdiri atas dua jenis. Angket pertama yang diisi oleh karyawan tetap adalah mengenai lingkungan kerja dan disiplin kerja, terdapat juga profil responden (nama, jenis kelamin, usia, tingkat pendidikan, lama bekerja dan bagian divisi) dan pertanyaan terbuka. Angket kedua yang diisi oleh kepala divisi adalah mengenai nama karyawan, bagian divisi dan kinerja karyawan. Pengukuran variabel dalam penelitian ini menggunakan skala likert dalam bentuk pernyataan positif, terdiri atas skor 1 hingga 5 yang artinya sangat tidak setuju, tidak setuju, ragu-ragu, setuju dan sangat setuju.

Pengolahan data dalam penelitian ini menggunakan Program SPSS for Windows version 19. Tahap- tahap pengolahan data dalam penelitian ini terdiri atas uji kesahihan, uji keterandalan, dan uji asumsi klasik. Tujuan uji kesahihan adalah untuk menunjukkan sejauh mana suatu alat ukur mampu mengukur apa yang ingin diukur. Hasil uji kesahihan variabel lingkungan kerja, disiplin kerja, dan kinerja karyawan dinyatakan sahih dengan nilai Pearson Correlation di atas 0,3 ( $r$ kritis) dan nilai Sig. (2-tailed) kurang dari 0,05 (Kuncoro, 2013, p.181).

Tujuan uji keterandalan adalah untuk menunjukkan sejauh mana pengukuran tersebut dilakukan tanpa ada kesalahan dan menjamin pengukuran yang konsisten, dengan nilai Cronbach Alpha lebih besar dari 0,6 (Kuncoro, 2013, p. 181). Hasil uji keterandalan dapat dilihat di Tabel 1.

\section{Tabel 1}

\section{Uji Keterandalan}

\begin{tabular}{lcc}
\hline \multicolumn{1}{c}{ Variabel } & Cronbach Alpha & Keterangan \\
\hline Lingkungan Kerja & 0,931 & Terandal \\
Disiplin Kerja & 0,909 & Terandal \\
Kinerja Karyawan & 0,909 & Terandal \\
\hline
\end{tabular}

Tujuan tahap pengolahan data yang terakhir adalah untuk mengetahui pola dan varian serta kelinieritasan suatu data (Kuncoro, 2013), yang terdiri atas uji normalitas, uji multikolinearitas, dan uji heteroskedastisitas. Berdasarkan One Sample Kolmogorov-Smirnov Test dan analisis grafik (normal P-P plot), hasil uji normalitas dinyatakan berdistribusi normal dengan nilai signifikansinya lebih besar dari 0,05 dan titiktitik menyebar di sekitar garis dan mengikuti garis diagonal (normal P-P plot) (Priyatno, 2012, p.51 \& 53). Hasil uji multikolinearitas juga dinyatakan tidak terjadi korelasi yang sempurna antara variabel bebas. Hal ini dapat ditunjukkan dari nilai Tolerance dan $\mathrm{Va}$ riance Infating Factor (VIF) masing-masing variabel bebas yang lebih besar dari 0,1 dan lebih kecil dari 10 (Priyatno, 2012, p.56). Uji heteroskedastisitas dengan menggunakan metode Glejser dan metode grafik dinyatakan tidak terjadi heteroskedastisitas. Hal ini juga ditunjukkan dari nilai signifikansi masing-masing variabel yang berada di atas 0,05 dan titik-titik yang menyebar dengan pola yang tidak jelas pada grafik (Priyatno, 2012, p. $66 \& 69$ ).

Teknik analisis data dalam penelitian ini adalah analisis deskriptif variabel penelitian (lingkungan kerja, disiplin kerja dan kinerja karyawan), tabulasi silang (antara variabel penelitian dan profil responden), analisis regresi linear berganda, analisis koefisien determinasi dan pengujian hipotesis. 


\section{Analisis dan Pembahasan}

\section{Analisis Deskriptif Variabel Penelitian}

Analisis deskriptif variabel lingkungan kerja dapat dikategorikan tidak nyaman $(1,00-3,00)$ dan nyaman (3,01-5,00), variabel disiplin kerja dan kinerja karyawan dapat dikategorikan rendah (1,00-3,00) dan tinggi $(3,01-5,00)$. Analisis deskriptif tersebut dapat dilihat di Tabel 2, 3, dan 4. Rata-rata dari seluruh pernyataan variabel lingkungan kerja yakni sebesar 3,47, yang artinya karyawan merasa nyaman dengan lingkungan kerja. Nilai rata-rata tertinggi terdapat pada pernyataan udara yang sejuk di tempat kerja membantu saya dalam bekerja dan rata-rata indikator tertinggi juga terdapat pada suhu udara di tempat kerja. Menurut Sedarmayanti (2007), suhu udara dapat mempengaruhi karyawan baik secara langsung maupun tidak langsung (dalam Norianggono, Hamid, \& Ruhana, 2014).

Rata-rata dari seluruh pernyataan variabel disiplin kerja adalah 3,29, yang artinya karyawan memiliki disiplin kerja yang tinggi. Ketepatan waktu kerja dan kepatuhan terhadap peraturan perusahaan merupakan indikator tertinggi pertama dan kedua, yaitu sebesar 3,35 dan 3,33. Disiplin yang tinggi memberikan manfaat yang besar bagi perusahaan maupun bagi para karyawan. Manfaat bagi perusahaan adalah terpeli- haranya tata tertib dan kelancaran pelaksanaan tugas hingga diperoleh hasil yang maksimal dan manfaat bagi para karyawan adalah menciptakan suasana kerja yang menyenangkan sehingga para karyawan dapat melaksanakan pekerjaannya dengan penuh kesadaran (Sutrisno, 2009).

Pengukuran kinerja karyawan perlu dilakukan untuk mengetahui apakah karyawan tersebut telah menyelesaikan kewajibannya sesuai waktu yang ditentukan atau menyimpang dari rencana yang telah ditetapkan (Wibowo, 2007, p. 155). Pengukuran kinerja karyawan dilakukan berdasarkan ketepatan waktu dalam menyelesaikan pekerjaan, tingkat inisiatif karyawan dan kemampuan karyawan dalam bekerja sama. Rata-rata kinerja karyawan secara keseluruhan adalah 3,24, yang artinya karyawan memiliki kinerja yang tinggi.

\section{Analisis Regresi Linear Berganda}

Berdasarkan Tabel 5, diperoleh persamaan regresi linear berganda sebagai berikut:

$$
Y=-0,920+0,710 X_{1}+0,516 X_{2}
$$

Keterangan:

$Y=$ Variabel kinerja karyawan

$X_{I}=$ Variabel lingkungan kerja

$X_{2}=$ Variabel disiplin kerja

$a=$ Konstanta

Tabel 2

Analisis Deskriptif Lingkungan Kerja

\begin{tabular}{|c|c|c|c|}
\hline Indikator & Pernyataan & $\begin{array}{c}\text { Nilai } \\
\text { Rata-Rata }\end{array}$ & $\begin{array}{c}\text { Nilai } \\
\text { Rata-Rata Indikator }\end{array}$ \\
\hline \multirow{2}{*}{$\begin{array}{l}\text { Suhu udara di tempat } \\
\text { kerja }\end{array}$} & Tempat kerja saya mempunyai udara yang sejuk & 3,58 & \multirow{2}{*}{3,63} \\
\hline & Udara yang sejuk di tempat kerja membantu saya dalam bekerja & 3,67 & \\
\hline \multirow{3}{*}{$\begin{array}{l}\text { Tata ruang di tempat } \\
\text { kerja }\end{array}$} & Penataan ruang di tempat kerja saya sangat teratur & 3,53 & \multirow{3}{*}{3,43} \\
\hline & Penataan ruang di tempat kerja saya sangat rapi & 3,50 & \\
\hline & $\begin{array}{l}\text { Penataan ruang di tempat kerja saya disesuaikan dengan } \\
\text { kebutuhan }\end{array}$ & 3,25 & \\
\hline \multirow{2}{*}{$\begin{array}{l}\text { Sirkulasi di tempat } \\
\text { kerja }\end{array}$} & Sirkulasi udara di tempat kerja saya bergantung pada AC & 3,58 & \multirow[b]{2}{*}{3,41} \\
\hline & $\begin{array}{l}\text { Sirkulasi udara (bergantung pada AC) di tempat kerja } \\
\text { membantu saya dalam bekerja }\end{array}$ & 3,25 & \\
\hline \multirow{2}{*}{$\begin{array}{l}\text { Tingkat pencahayaan } \\
\text { di tempat kerja }\end{array}$} & Tingkat pencahayaan di tempat kerja saya sudah terang & 3,52 & \multirow[b]{2}{*}{3,41} \\
\hline & $\begin{array}{l}\text { Tingkat pencahayaan yang terang di tempat kerja membantu } \\
\text { saya dalam bekerja }\end{array}$ & 3,30 & \\
\hline \multirow{2}{*}{$\begin{array}{l}\text { Hubungan antar } \\
\text { karyawan di tempat } \\
\text { kerja }\end{array}$} & Saya memiliki banyak rekan kerja di tempat kerja & 3,55 & \multirow[b]{2}{*}{3,58} \\
\hline & Saya cenderung makan siang bersama dengan rekan kerja & 3,60 & \\
\hline \multirow{4}{*}{$\begin{array}{l}\text { Hubungan karyawan } \\
\text { dengan pemimpin } \\
\text { perusahaan di tempat } \\
\text { kerja }\end{array}$} & $\begin{array}{l}\text { Saya dapat berkomunikasi dengan nyaman dengan pemimpin } \\
\text { perusahaan (tidak gerogi) }\end{array}$ & 3,50 & \multirow{3}{*}{3,42} \\
\hline & $\begin{array}{l}\text { Pemimpin perusahaan cenderung menyempatkan waktu untuk } \\
\text { melihat kinerja saya }\end{array}$ & 3,50 & \\
\hline & $\begin{array}{l}\text { Pemimpin perusahaan cenderung bertukar informasi dengan } \\
\text { saya }\end{array}$ & 3,25 & \\
\hline & Total & \multicolumn{2}{|r|}{3,47} \\
\hline
\end{tabular}


Tabel 3

Analisis Deskriptif Disiplin Kerja

\begin{tabular}{|c|c|c|c|}
\hline Indikator & Pernyataan & $\begin{array}{c}\text { Nilai } \\
\text { Rata-Rata }\end{array}$ & $\begin{array}{c}\text { Nilai } \\
\text { Rata-Rata Indikator }\end{array}$ \\
\hline \multirow[t]{4}{*}{ Ketepatan waktu kerja } & Saya datang lebih awal di tempat kerja & 3,50 & \multirow{4}{*}{3,34} \\
\hline & Saya pulang kerja sesuai dengan jam yang telah di tentukan & 3,28 & \\
\hline & Saya makan siang saat jam istirahat & 3,35 & \\
\hline & Saya kembali ke tempat kerja sebelum jam istirahat berakhir & 3,25 & \\
\hline Kerapian berpakaian & $\begin{array}{l}\text { Saya cenderung memperhatikan kerapian seragam saat jam } \\
\text { kerja }\end{array}$ & 3,17 & 3,17 \\
\hline \multirow{3}{*}{$\begin{array}{l}\text { Kepatuhan pada aturan } \\
\text { perusahaan }\end{array}$} & Saya hadir setiap hari di tempat kerja & 3,33 & \multirow{3}{*}{3,33} \\
\hline & $\begin{array}{l}\text { Saya memberikan surat keterangan dokter saat tidak masuk } \\
\text { kerja karena sakit }\end{array}$ & 3,20 & \\
\hline & $\begin{array}{l}\text { Saya memakai seragam dan atribut sesuai dengan hari yang } \\
\text { ditetapkan }\end{array}$ & 3,48 & \\
\hline \multirow[t]{3}{*}{ Tanggung jawab } & Saya mengerjakan tugas dengan tanggung jawab & 2,95 & \multirow[b]{2}{*}{3,15} \\
\hline & $\begin{array}{l}\text { Saya siap bertanggung jawab atas kesalahan yang telah } \\
\text { dilakukan }\end{array}$ & 3,35 & \\
\hline & Total & \multicolumn{2}{|r|}{3,29} \\
\hline
\end{tabular}

Tabel 4

Analisis Deskriptif Kinerja Karyawan

\begin{tabular}{|c|c|c|c|}
\hline Indikator & Pernyataan & $\begin{array}{c}\text { Nilai } \\
\text { Rata-Rata }\end{array}$ & $\begin{array}{c}\text { Nilai } \\
\text { Rata-Rata Indikator }\end{array}$ \\
\hline \multirow[t]{3}{*}{$\begin{array}{l}\text { Ketepatan waktu dalam } \\
\text { menyelesaikan pekerjaan }\end{array}$} & $\begin{array}{l}\text { Karyawan mampu menyelesaikan pekerjaan dengan tepat } \\
\text { waktu }\end{array}$ & 3,30 & \multirow{3}{*}{3,29} \\
\hline & $\begin{array}{l}\text { Karyawan mampu menyelesaikan pekerjaan sesuai jumlah } \\
\text { yang ditentukan dengan tepat waktu }\end{array}$ & 3,37 & \\
\hline & $\begin{array}{l}\text { Karyawan mampu menyelesaikan pekerjaan sesuai kualitas } \\
\text { yang ditentukan dengan tepat waktu }\end{array}$ & 3,20 & \\
\hline \multirow[t]{2}{*}{ Tingkat inisiatif karyawan } & Karyawan memiliki inisiatif dalam bekerja & 3,27 & \multirow{2}{*}{3,20} \\
\hline & Karyawan memiliki inisiatif dalam memperbaiki kesalahan & 3,12 & \\
\hline \multirow[t]{2}{*}{$\begin{array}{l}\text { Kemampuan Karyawan } \\
\text { dalam bekerja sama }\end{array}$} & $\begin{array}{l}\text { Karyawan mampu bekerja sama dengan rekan kerja satu } \\
\text { divisi }\end{array}$ & 2,93 & \multirow{2}{*}{3,20} \\
\hline & $\begin{array}{l}\text { Karyawan mampu bekerja sama dengan rekan kerja di } \\
\text { divisi lain }\end{array}$ & 3,48 & \\
\hline \multicolumn{2}{|r|}{ Total } & \multicolumn{2}{|r|}{3,24} \\
\hline
\end{tabular}

\section{Tabel 5}

Analisis Regresi Linear Berganda

\begin{tabular}{lc}
\hline \multicolumn{1}{c}{ Variabel } & Unstandardized Coefficients \\
\hline Konstanta & $-0,920$ \\
\hline Lingkungan Kerja & 0,710 \\
\hline Disiplin Kerja & 0,516 \\
\hline
\end{tabular}

Berdasarkan hasil persamaan regresi linear berganda tersebut, dapat dijelaskan sebagai berikut:

- Nilai -0,920 adalah konstanta yang menunjukkan rendahnya kualitas kinerja karyawan sebesar 0,92, apabila lingkungan kerja dan disiplin kerja tidak berpengaruh terhadap kinerja karyawan.

- Koefisien regresi variabel lingkungan kerja sebesar 0,710. Koefisien regresi tersebut menunjukkan bahwa setiap terjadi peningkatan lingkungan kerja, maka kinerja karyawan akan meningkat sebesar 0,701 .

- Koefisien regresi variabel disiplin kerja sebesar 0,516. Koefisien regresi tersebut menunjukkan bahwa setiap terjadi peningkatan disiplin kerja, maka kinerja karyawan akan meningkat sebesar 0,516 .

\section{Analisis Koefisien Determinasi}

Tabel 6

Analisis Koefisien Determinasi

\begin{tabular}{ccccc}
\hline Model & $\mathrm{R}$ & R Square & $\begin{array}{c}\text { Adjusted } R \\
\text { Square }\end{array}$ & $\begin{array}{c}\text { Std. Error of } \\
\text { the Estimate }\end{array}$ \\
\hline 1 & $0,945^{\mathrm{a}}$ & 0,893 & 0,887 & 0,27587 \\
\hline
\end{tabular}


Tabel 6 menunjukkan bahwa nilai koefisien determinasi sebesar 0,893 atau $89,3 \%$, yang artinya lingkungan kerja dan disiplin kerja memiliki pengaruh sebesar $89,3 \%$ terhadap kinerja karyawan dan sisanya sebesar $10,7 \%$ dipengaruhi oleh variabel lainnya.

\section{Pengujian Hipotesis}

Tabel 7

Uji $t$

\begin{tabular}{lccc}
\hline Variabel & $t$ tabel & $t$ hitung & Signifikansi Hitung \\
\hline Lingkungan Kerja & 1,684 & 3,866 & 0,00 \\
Disiplin Kerja & 1,684 & 4,165 & 0,00 \\
\hline
\end{tabular}

Tabel 7 menunjukkan bahwa $t$ hitung dari lingkungan kerja dan disiplin kerja lebih besar daripada $t$ tabel $(1,684)$, yakni sebesar 3,866 dan 4,165. Cara kedua dapat dilihat dari nilai signifikansi. Nilai signifikansi lingkungan kerja dan disiplin kerja lebih kecil daripada 0,05, yakni masing-masing sebesar 0,00 . Berdasarkan ketentuan di atas, hasil yang diperoleh adalah hipotesis nol $\left(H_{0}\right)$ ditolak, sehingga pernyataan mengenai variabel lingkungan kerja atau disiplin kerja tidak berpengaruh pada kinerja karyawan tersebut ditolak. Dengan kata lain, hipotesis alternatif $\left(H_{a}\right)$ diterima, sehingga variabel lingkungan kerja atau disiplin kerja berpengaruh terhadap kinerja karyawan.

Hasil uji $t$ menunjukkan bahwa hipotesis pertama $\left(H_{l}\right)$ dinyatakan terbukti. Hal ini menunjukkan bahwa lingkungan kerja berpengaruh terhadap kinerja karyawan. Hasil ini mendukung penelitian yang dilakukan oleh Norianggono, Hamid, dan Ruhana (2014) yang menyatakan bahwa lingkungan kerja merupakan salah satu faktor yang mempengaruhi kinerja karyawan dikarenakan lingkungan kerja berada paling dekat dengan karyawan dalam melaksanakan pekerjaannya, maka diperlukan perhatian yang khusus dari perusahaan agar memberikan dampak yang positif bagi kinerja karyawan tersebut.

Lingkungan kerja tersebut terdiri atas lingkungan kerja fisik dan non fisik. Lingkungan kerja fisik adalah keadaan di sekitar tempat kerja yang berbentuk fisik yang dapat mempengaruhi karyawan secara langsung (kursi, meja dan lain-lain) maupun tidak langsung (temperatur, kelembaban, sirkulasi udara dan lain-lain), sedangkan lingkungan kerja non fisik adalah keadaan yang terjadi yang berkaitan dengan hubungan kerja, baik hubungan dengan atasan maupun hubungan dengan sesama rekan kerja ataupun hubungan dengan bawahan (Sedarmayanti, 2007). Menurut Febriani dan Indrawati (2013), dan Situngkir (2013), menjaga kenyamanan dan kebersihan lingkungan kerja juga merupakan faktor yang harus diperhatikan dan mempengaruhi karyawan dalam menyelesaikan pekerjaannya.
Hasil uji $t$ menunjukkan bahwa hipotesis kedua $\left(\mathrm{H}_{2}\right)$ dinyatakan tebukti. Hal ini menunjukkan bahwa disiplin kerja berpengaruh terhadap kinerja karyawan. Hasil penelitian ini didukung oleh penelitian yang dilakukan oleh Rofi (2012) yang menyatakan bahwa disiplin kerja merupakan faktor yang paling dominan dalam mempengaruhi sehingga disiplin kerja perlu ditingkatkan agar harapan karyawan dapat tercapai dan karyawan mendapatkan kepuasan dalam bekerja. Disiplin kerja yang dimiliki oleh karyawan memberikan manfaat bagi perusahaan dan karyawan tersebut (Sutrisno, 2009). Menurut Branham (2010) setiap karyawan yang tidak memiliki kesadaran mengenai disiplin kerja akan melakukan pelanggaran yang sama dan akan berdampak terhadap kinerja karyawan tersebut (dalam Prabasari \& Netral, 2013).

\section{Tabel 8}

Uji $F$

\begin{tabular}{lc}
\hline Variabel & Signifikansi Hitung \\
\hline Lingkungan Kerja & 0,00 \\
Disiplin Kerja & \\
\hline
\end{tabular}

Tabel 8 menunjukkan bahwa nilai signifikansi < 0,05 yaitu sebesar 0,00 sehingga hipotesis nol $\left(H_{0}\right)$ ditolak. Oleh karena itu penyataan mengenai lingkungan kerja dan disiplin kerja tidak berpengaruh pada kinerja karyawan tersebut ditolak. Dengan kata lain, hipotesis alternatif $\left(H_{a}\right)$ diterima, yang artinya variabel lingkungan kerja dan disiplin kerja berpengaruh terhadap kinerja karyawan. Hal ini menunjukkan bahwa hipotesis ketiga $\left(\mathrm{H}_{3}\right)$ dinyatakan terbukti. Penelitian mendukung penelitian yang dilakukan oleh Pramana dan Sudharma (2013) yang menyatakan bahwa lingkungan kerja yang nyaman dapat membuat karyawan bersemangat dalam bekerja. Hal ini menunjukkan bahwa karyawan tersebut memiliki tanggung jawab yang besar, sehingga kinerja karyawan tersebut meningkat. Menurut Suryadi dan Rosyidi (2013), perasaan senang yang ditunjukkan karyawan mencerminkan lingkungan kerja yang nyaman dan didukung dengan peraturan perusahaan yang sesuai.

\section{Simpulan dan Implikasi}

Berdasarkan hasil uji $t$ dan uji $F$, maka dapat disimpulkan bahwa lingkungan kerja berpengaruh terhadap kinerja karyawan. Hasil ini mendukung penelitian terdahulu yang dilakukan oleh Norianggono, Hamid dan Ruhana (2014) yang menyatakan bahwa lingkungan kerja merupakan salah satu hal yang dapat mempengaruhi kinerja karyawan. Hal ini dikarena lingkungan kerja berada paling dekat dengan karyawan dalam melaksanakan pekerjaannya. Oleh karena 
itu, diperlukan perhatian yang khusus dari perusahaan agar dapat memberikan dampak yang positif bagi kinerja karyawan. Disiplin kerja berpengaruh terhadap kinerja karyawan. Hal ini mendukung penelitian yang dilakukan Rofi (2012) yang menyatakan bahwa disiplin kerja merupakan faktor yang paling dominan dalam mempengaruhi kinerja karyawan. Oleh karena itu, disiplin kerja perlu ditingkatkan agar harapan karyawan dapat tercapai, karyawan mendapatkan kepuasan dalam bekerja dan karyawan dapat meningkatkan kinerja karyawan. Lingkungan kerja dan disiplin kerja berpengaruh signifikan terhadap kinerja karyawan. Penelitian ini mendukung hasil penelitian terdahulu yang dilakukan oleh Pramana dan Sudharma (2013) yang mengatakan bahwa lingkungan kerja yang nyaman dapat membuat karyawan bersemangat dalam bekerja. Hal ini menunjukkan bahwa karyawan tersebut memiliki tanggung jawab yang besar, sehingga kinerja karyawan meningkat.

Hasil penelitian memberikan implikasi untuk peningkatan kenyamanan lingkungan kerja, tingkat disiplin kerja dan kinerja karyawan khususnya pada lingkungan perbankan. Perhatian dan pembaharuan fasilitas kerja yang dibutuhkan oleh karyawan penting untuk kenyamanan karyawan terjaga dan mendukung karyawan dalam bekerja. Di samping itu, peningkatan disiplin kerja dengan cara memberikan award bagi karyawan yang memiliki disiplin kerja yang tinggi penting untuk dipertimbangkan agar karyawan termotivasi untuk meningkatkan disiplin kerja dan dapat menjadi contoh bagi karyawan lainnya. Pemberian reward berupa insentif bagi karyawan yang berprestasi perlu mendapat perhatian agar dapat memotivasi karyawan untuk meningkatkan kinerjanya. Dalam penelitian selanjutnya perlu menambahkan variabel bebas, seperti insentif dan pelatihan, agar menghasilkan penelitian baru yang dapat membantu perusahaan dalam meningkatkan kinerja karyawan.

\section{Daftar Referensi}

Abdullah, M. (2014). Manajemen dan evaluasi kinerja karyawan. Yogyakarta: Aswaja Pressindo.

Agastia, A. (2014). Pengaruh lingkungan kerja fisik, komunikasi, dan kepemimpinan terhadap kinerja karyawan PT BPR Merta Sedana Badung. EJurnal Manajemen Universitas Udayana, 3(1), $29-44$.

Ardiansyah \& Wasilawati. (2014). Pengaruh Pengawasan dan Disiplin Kerja terhadap Kinerja Karyawan Badan Pusat Statistik Kabupaten Lampung Tengah. Jurnal Manajemen Kewirausahaan, 16(2), 153-162.
Ariana, T. \& Riana. (2013). Pengaruh kepemimpinan, kompensasi dan disiplin kerja terhadap kinerja karyawan pada Hotel Cendana Resort dan Spa Ubud, Gianyar. E-Jurnal Manajemen Universitas Udayana, 2(1), 121-136.

Bangun, W. (2012). Manajemen sumber daya manusia. Jakarta: Erlangga.

Cahyani, N. \& Ardana, K. (2013). Pengaruh lingkungan kerja fisik, gaya kepemimpinan dan insentif finansial terhadap kinerja pegawai non medis pada rumah sakit Balimed Denpasar. $E$ Jurnal Manajemen Universitas Udayana, 2(4), 423-435.

Dharmawan, Y. (2011). Pengaruh kompensasi dan lingkungan kerja non fisik terhadap disiplin dan kinerja karyawan Hotel Nikki Denpasar. Thesis tidak dipublikasikan. Diunduh September 5, 2014 dari http://www.pps.unud.ac.id/thesis/pdf _thesis/unud-382-1739441302-pengaruh\%20 kompensasi\%20dan\%20lingkungan\%20ker ja\%20non\%20fisik\%20terhadap\%20disiplin.pdf

Dwipayana, M. A. (2014). Pengaruh disiplin kerja, motivasi dan gaya kepemimpinan terhadap kinerja karyawan pada percetakan Sadha Jaya di Denpasar. E-Jurnal Manajemen Universitas Udayana, 3(1), 225-242.

Erry. (2014). Bekerja dan bersantai di kantor baru Google. Diunduh September 5, 2014, dari http:// www.infokomputer.com/2014/03/ fitur/kantorbaru-google-indonesia/.

Febriani, T. \& Indrawati, D. (2013). Pengaruh motivasi, kompensasi, serta lingkungan kerja fisik terhadap kinerja karyawan hotel The Niche Bali. E-Jurnal Manajemen Universitas Udayana, 2(5), 541-551.

Hasibuan, M. S. P. (2003). Manajemen sumber daya manusia. Edisi Revisi. Cetakan Keenam. Jakarta: PT Bumi Aksara.

Indrajaya, A. \& Adnyani, A. (2013). Pengaruh budaya organisasi, komunikasi dan lingkungan kerja terhadap produktivitas kerja karyawan CV Hitakara Denpasar. E-Jurnal Manajemen Universitas Udayana, 2(4), 410-421.

Kepakisan, B. (2014). Pengaruh motivasi, disiplin dan kepemimpinan terhadap kinerja karyawan di PT Bank BPD Bali Cabang Tabanan. E-Jurnal Manajemen Universitas Udayana, 3(1), 401-413.

Kuncoro, M. (2013). Metode riset untuk bisnis dan ekonomi. Jakarta: Erlangga.

Krisnanda, N. A. \& Sudibya, G. A. (2014). Pengaruh disiplin kerja, motivasi kerja dan kompensasi terhadap kinerja karyawan Respati Sanur Beach Hotel. E-Jurnal Manajemen Universitas Udayana, 3(7), 2101-2114.

Mangkunegara, A. P. (2009). Evaluasi kinerja sdm. Bandung: PT Refika Aditama. 
Norianggono, Y., Hamid, D., \& Ruhana, I. (2014). Pengaruh lingkungan kerja fisik dan non fisik terhadap kinerja karyawan (studi pada karyawan PT Telkomsel Area III Jawa-Bali di Surabaya). Jurnal Administrasi Bisnis, 8(2), 1-10.

Nurcahyo, A. (2011). Analisis variabel-variabel yang mempengaruhi kinerja karyawan pada PT Quadra Mitra Perkasa Balikpapan. Jurnal Eksis, 7 (2), 1972-1982

Parhusip, C. M. D., Musadieq, M., \& Nurtjahjono, G.E. (2014). Pengaruh disiplin kerja terhadap prestasi kerja (studi pada karyawan AJB BUMIPUTERA 1912 Cabang Kayutangan Kota Malang). Jurnal Administrasi Bisnis, 9(1), 1-10.

Prabasari, M. \& Netra, K. (2013). Pengaruh motivasi, disiplin kerja dan komunikasi terhadap kinerja karyawan PT PLN (Persero) distribusi Bali. $E$ Jurnal Manajemen Universitas Udayana, 2(4), 469-481.

Pramana, K. \& Sudharma, I. N. (2013). Pengaruh kompensasi, lingkungan kerja fisik dan disiplin kerja terhadap kinerja karyawan. E-Jurnal Manajemen Universitas Udayana, 2(9), 1175-1188.

Priyatno, D. (2012). Cara kilat belajar analisis data dengan SPSS 20. Edisi Kesatu. Yogyakarta: ANDI.

Rivai, V. \& Sagala, J. (2009). Manajemen sumber daya manusia untuk perusahaan. Jakarta: PT Raja Grafindo Persada.

Rofi, A. (2012). Pengaruh disiplin kerja dan pengalaman kerja terhadap prestasi kerja karyawan pada departemen produksi PT Leo Agung Raya Semarang. Jurnal Ilmu Manajemen dan Akuntansi Terapan, 3(1), 1-21.
Sanjaya, E. \& Indrawati, D. (2014). Pengaruh kompetensi, kompensasi dan lingkungan kerja terhadap kinerja karyawan pada PT Pande Agung Segara Dewata. E-Jurnal Manajemen Universitas, 3(1), 205-224.

Sedarmayanti. (2007). Manajemen sumber daya manusia reformasi birokrasi dan manajemen pegawai negeri sipil. Bandung: PT Refika Aditama

Setiawan, F. \& Dewi, K. (2014). Pengaruh kompensasi dan lingkungan kerja terhadap kinerja karyawan pada CV Berkat Anugrah. E-Jurnal Manajemen Universitas Udayana, 3(5), 14711490.

Siagan, S. P. (2014). Manajemen sumber daya manusia. Jakarta: Bumi Aksara.

Singodimedjo, M. (2002). Manajemen sumber daya manusia, Surabaya: SMMAS.

Situngkir, S. A. (2013). Pengaruh kompensasi finansial, hubungan kerja, dan lingkungan kerja fisik terhadap kinerja karyawan pada perusahaan daerah parkir kota Denpasar. E-Jurnal Manajemen Universitas Udayana, 2(8), 1019-1035.

Suryadi, A. \& Rosyidi, H. (2013). Kinerja karyawan ditinjau dari analisi faktor budaya perusahaan. Jurnal Penelitian Psikologi, 4(2), 166-180.

Sutrisno, E. (2009). Manajemen sumber daya manusia. Jakarta: Kencana.

Wibowo. (2007). Manajemen kinerja. Edisi Keempat. Jakarta: PT Raja Grafindo Persada.

Yasa, S. \& Utama, M. (2014). Pengaruh kompensasi dan lingkungan kerja terhadap kepuasaan kerja dan kinerja karyawan pada Karma Jimbaran. EJurnal Manajemen Universitas Udayana, 3(3), 609-623. 